\title{
Exploration on Training Mode for Entrepreneurial Talents in Financial Management Major of Local Regular Colleges
}

\author{
Guo Wei \\ Economic and Management College \\ Baicheng Normal University \\ Baicheng, Jilin Province, China
}

\begin{abstract}
With the faster pace of the comprehensive in-depth reform in China, the society has higher requirements for the entrepreneurial talents of financial management major. The teaching for the financial management major in the local regular colleges in China should adapt to the new development trends and keep in pace with the times. Better teaching for the financial management major in local regular colleges is of great importance for the development in the new period of China. There is a great necessity for the talents of financial management major, which makes the cultivation of financial management talents a significant job for the higher education in China. In this paper, it will make an analysis and exploration for the training mode of entrepreneurial talents of financial management major in local regular colleges.
\end{abstract}

Keywords- local regular colleges; financial management major; entrepreneurial talent; training mode

\section{INTRODUCTION}

Financial management talent is an indispensable element for the daily operation of company while the colleges in China have been important places for cultivation of these talents. With the reforms in advanced education institutions in China and the changes of social concept, simple and traditional training for financial management talents cannot satisfy the actual demands in the current society of China. Therefore, apart from setting up financial management curriculum, the relevant colleges are required to make comprehensive and effective in-depth reforms so that the advanced education in China can adapt to the new development trends and cultivate financial managerial talents and entrepreneurial talents that can conform to the requirements of times and the graduates can have good performance after graduation and have stronger independent option ability and entrepreneurship.

\section{Problems EXISTING IN THE CURRENT TRAINING MODE FOR ENTREPRENEURIAL TALENTS IN FINANCIAL MANAGEMENT MAJOR OF LOCAL REGULAR COLLEGES}

\section{A. Insufficiency of entrepreneurship in teaching staff}

The cultivation of entrepreneurs in colleges cannot be simply satisfied by financial managerial knowledge but also requires the joint efforts of many disciplines and many skills. As for the teaching staff of financial management major, though they have strong theoretical knowledge and scientific research ability in expertise of financial management, they put too much emphasis to the teaching of theories and they are keen on the traditional teaching mode. Therefore, they have some insufficiencies during the entrepreneurship and the actual operation of financial management, such as strong theoretical knowledge and weak practical ability, which, of course, will have some negative influence on the teaching effect to some extent.

\section{B. Comparatively monotonous teaching content}

The current teaching for financial management major in China put much more emphasis on the teaching of relevant knowledge to the financial management major. Though students can have comparatively solid financial management knowledge by such teaching method, they have weakness in the actual entrepreneurship for they cannot dynamically integrate the theory with the practice, therefore, the students lack of practical ability after learning. Although parts of the colleges set up practical teaching curriculum, it is hard for them to design the teaching contents comprehensively according to the features of financial management majors in colleges and the characteristics of social practical entrepreneurship because of the setting up of the contents and the restrictions of traditional teaching mode. Therefore, there is the shortcoming of routinization and theorization, which makes the teaching contents monotonous.

\section{Relative backwardness of teaching method}

The financial management major requires relevant theoretical background. However, in the actual teaching process, the traditional teaching mode is relatively lagging behind. In the rapid developed economic society, the teaching of financial management major should adapt to the development of the times and keep in pace with the development. The practicalness of the financial management major should be strengthened and the training for the professional skills should be enhanced. Meanwhile, it is necessary to strengthen the innovation ability and entrepreneurship as well as the consciousness to start up a business and the competitive consciousness after graduation and working.

Therefore, only by the theoretical instilment through traditional teaching mode or even the "teacher-centered while students just watching" mode cannot conform to the teaching objectives of new times. 


\section{MEASURES FOR THE CULTIVATION OF FinANCIAL MANAGEMENT ENTREPRENEURIAL TALENTS}

\section{A. Enhancement for the construction of teaching staff}

It is crucial to establish the teaching staff with excellent entrepreneurship and strong financial management knowledge in order to make better effect for the teaching of financial entrepreneurship in colleges. Therefore, the colleges are required to pay much emphasis to the construction of teaching staff and the cultivation of relevant teachers and staff as well as actively recommend the excellent talents of financial management to the relevant advanced curriculum training and communicative seminars as well as higher research platform, which can improve the overall quality of the teachers in this process. Apart from "sending the teachers out", the colleges should invite the new teachers which include celebrated successful entrepreneurs, outstanding innovative talents, experts from banks as well industrial and commercial circles to supervise the entrepreneurship of the students, during which these teachers can display and impart the advanced entrepreneurship and the latest technological achievements to the students so that they can improve the financial management entrepreneurship and innovative consciousness to the greatest extent.

\section{B. Optimization of the teaching method}

Good teaching method often brings better results during the actual teaching process. In order to make the actual teaching better highlight that the students are equipped with higher financial management ability and entrepreneurship, colleges should make research and innovation to the existing teaching methods and approaches as well as teach through many methods, such as actual participation, group discussion, exploration to theories and practices as well as heuristics to the thinking and so on, so as to really change the backward teaching concept of teachers and students through innovations and optimization of previous teaching modes, which can make the students transfer from the conscious of "know", "understand" to the conscious of "how to finish" and actually improve the innovation ability and entrepreneurship as well as the comprehensive career ability.

\section{Innovations to the financial management curriculum system}

During the teaching process, colleges should improve and perfect the original curriculum system so as to make the professional level and practical ability to an ideal extent. Firstly, the financial management major in colleges should focus on the construction of specialized courses and assist by relevant courses for innovation education as well as supplement by forum and seminars so as to mutually establish the cultivation system of financial management talents. The specialized courses should be important professional courses, such as Elementary Financial Management, Intermediate Financial Management, Advanced Financial Management, Micro-economics, Macroeconomics, Money and Banking, Financial Securities Investment, Project Evaluation, Multinational Corporation Finance and so on. And the supplementary courses mainly include Creatology. Theory and Practice on Innovative Entrepreneurship, Control on Entrepreneurship Risk, Career Planning and the relevant methods and skills for the entrepreneurial practice. Meanwhile, the colleges should constantly connect the social reality to add up the necessary new courses and new technology for the students during the actual teaching process so as to promote the development of comprehensive ability of the students.

\section{Initiation of multiple practical modes for students}

Practice is the best teacher. After optimization of the curriculum system and content, colleges should help the students participate in the practice by various methods so that they can actually put what they have learned into the practice and learn how to use during the actual practice. Firstly, colleges should develop different training projects for the students and bring the corporate into the campus by relevant preferential policy and combination of actual situation of the college and the district it belongs to, which can affect the students by the actual operation modes of the corporate and help the students participate in the real training and study the knowledge and experience during the entrepreneurship after finishing it. Therefore, students can play the relevant financial role in the actual operation, which is good experience and improvement for the development of the training mode for the entrepreneurial talents of financial management major in colleges as well as the learning effects of the students. Secondly, participation in association in colleges is also a good method. By calling upon the students to set up relevant associations, clubs etc on financial managements, it can better organize the students with entrepreneurship intentions and mutually promote and improve the students through a series of simulation corporate and discussions on entrepreneurial knowledge and other activities, which can make students have better achievement through mutual encouragement. Finally, colleges can hold various competitions on creative entrepreneurship, such as practice room for entrepreneurship, creative designing competition etc, which can effectively stimulate the entrepreneurial spirit and creative enthusiasm of the students and obtain better entrepreneurship under the racing and fierce competitive environment.

\section{E. Better support for the entrepreneurship of the students}

The entrepreneurship of the students will confront with tremendous difficulties and pressure from various aspects, which requires the encouragement and support of the teachers from various aspects apart from the improvement of financial management ability and initiative ability. Firstly, colleges should assess the comprehensive quality and competence on entrepreneurship of the students by individualized method and multiple ways and observe the research the professional ability on researching and solving the relevant entrepreneurial financial management of the students by this method. Secondly, when thinking of that the students have equipped with the primary initiative competence, teachers should integrate the relevant resources as much as possible to support the entrepreneurship of the students. For example, the colleges should establish a start- 
up district for students by connection with the government and the local technology zones so as to build up a good entrepreneurial atmosphere for the students under such environment. Meanwhile, colleges should provide facilities, places as well as articles etc if the conditions permit, so as to provide help to the entrepreneurship of the students in early period. Finally, colleges should provide capital support to the students through various channels, such as founding special entrepreneurial fund for students and providing small loans by combination with the banks nearby, which can help solve the problems of lack of capital for students.

\section{CONCLUSION}

The training for the entrepreneurial talents of financial management major is of great importance and active meaning to the future development of the economy in China. In the previous part, the training mode for entrepreneurial talents of financial management major in local colleges of China has been explored to certain extent. In the actual operation process, relevant colleges should connect with the reality of themselves so as to cultivate more financial management entrepreneurial talents more targetedly.

\section{References}

[1] Zhao Yu. Study and Practice on the Training Mode of Core Innovative Talents by the Construction of a Brand In Tianjing[J]. Education Teaching Forum. 2014(09):191-192.

[2] Tan Xiaofang \& Zhou Xianwen. On Status Quo and Optimization of the Training Mode for Financial Management Expertise[J]. Maritime Education Research .2013(03):90-92.

[3] Li Di. On the Exploration and Analysis of Practical Teaching of the Financial Management Major of Application-oriented Universities [J]. Business Economics. 2012(24):116-117.

[4] Duan Lin. On the Practice and Thinking of the Optimization of Training Mode of the Financial Management Major in Universities [J]. Journal of Hunan University of Finance and Economics. 2011(04):69-72.

[5] Li Wangguo. Exploration and Reform on the Training Mode of Application-oriented Talents Based on the Educational Concept of CDIO Project [J]. Economics Research Guide.2012(23):286-288. 